\title{
The Impact of Information and Communication Technology (ICT) on Rural Banks Management. A Case Study of Atiwa-Rural Bank Limited in Ghana
}

\author{
John Wiredu ${ }^{*}$, Usman Inuwa Labaran², Emmanuel Nketiah ${ }^{3}$, Benjamin Kwapong Osibo ${ }^{4}$ \\ ${ }^{1}$ School of Business, Nanjing University of Information Science \& Technology, Nanjing, China \\ ${ }^{2}$ School of Architecture and Construction, Nanjing Tech University, Nanjing, China \\ ${ }^{3}$ School of Economics and Management, Nanjing University of Science and Technology, Nanjing, China \\ ${ }^{4}$ School of Computer Science, Nanjing University of Information Science \& Technology, Nanjing, China \\ Email: *johnwiredu50@gmail.com, 202062126026@njtech.com,nketiah888@hotmail.com, osibobenjamin@gmail.com
}

How to cite this paper: Wiredu, J., Labaran, U. I., Nketiah, E., \& Osibo, B. K. (2020). The Impact of Information and Communication Technology (ICT) on Rural Banks Management. A Case Study of Atiwa-Rural Bank Limited in Ghana. American Journal of Industrial and Business Management, 10, 1681-1706.

https://doi.org/10.4236/ajibm.2020.1010106

Received: June 22, 2020

Accepted: October 26, 2020

Published: October 29, 2020

Copyright $\odot 2020$ by author(s) and Scientific Research Publishing Inc. This work is licensed under the Creative Commons Attribution International License (CC BY 4.0).

http://creativecommons.org/licenses/by/4.0/ (c) (i) Open Access

\begin{abstract}
The objective of this study is to assess the strategic Impact of Information, Communication and Technology (ICT) in the rural banking sector and the benefits of introducing ICT in Ghana. SPSS and Microsoft Excel were used to analyze the responses. The study reveals that the Atiwa Rural Bank lacks the desired technologies to support its operations but also had the advantages of limitation of customers' waiting time, fast business with customers, cut down on its operating costs, provision of convenient banking services to its customers and attraction of a large customer base thereby increasing its revenue volume and also experiencing a sharp increase in its profit level since the deployment of Information, Communication, and Technology into its systems. Again, Lack of funds, as well as restrictive ICT policies by supervisory bodies like the Bank of Ghana and the ARB Apex Bank, were found to be influencing against the utilization of Information, Communication, and Technology. The study recommended that the management of Atiwa rural banks should attempt to bring on board more innovative technologies to help the bank survive the current wave of competition in the banking industry so as to contribute its roles to the economic development of the nation.
\end{abstract}

\section{Keywords}

ICT, Management, Customers, Workers, Rural Banks, Ghana 


\section{Introduction}

\subsection{Background}

A nation cannot boast of development without having Information and Communication Technology (ICT) as its backbone. Therefore, a country's development is measured in terms of its overall social, political, and economic progress. Information and Communication Technology (ICT) is in recent times the highway on which the success of every Nation or organization relies and cruise. It is because of this that is why there is an everyday encouragement of every Country to improve the economic, social, and political relations. There is no doubt that ICT infrastructure development determines the rate of growth of a country or an organization as said by Lucas (2008), the ability to manage and maintain the ICT infrastructure effectively is key to the success of a Country and an organization and managers have vital roles to ensure that. Rural Banks existed to offer banking services to rural communities in which they operate. According to Kettinger et al. (1997), Rural Banks channel its investments mainly in the agricultural sector of the economy and in small and medium scale enterprises. Again, Laudon \& Laudon (2001), also said that banking as a form of the business venture was introduced into Ghana in the year 1896 by the colonial masters in the then Gold Coast to help in the governance of their colony. They are designed to serve the needs of rural communities.

Clearly, it could be seen that the Rural Banks are primarily established to render banking services to the rural communities in which they operate. The channel's investment is mainly in the agricultural sector of the economy and small and medium scale enterprises. And in doing so, the bank Managers perform a crucial role in ensuring successful banking operations and performance.

Again, they are specifically designed to serve the needs of rural communities. History has it that during Ghana's pre-colonial era, the system of trade among the people was termed barter trade whereby goods were exchanged for goods. Likewise, objects like shells, cowries, beads, etc., were adopted as a means of exchange. But as society grew more complex, these crude methods of exchange became unsatisfactory. According to (Guru et al., 2001), Coins and paper notes were later introduced, and this made it easy for any amount of goods and services to be acquired at the exchange of such coins and paper notes.

Because of the above-stated occurrence, the bank of Ghana conducted a study into the rural carry system in the 1970s. The study showed a noticeable gap in the existing banking and credit system "with insufficient funds flowing through the systems to a large number of rural borrowers who needed credit most" (Guru et al., 2001). The study recommended the establishment of rural banks in the country and delegates from the Bank of Ghana were sent to the Philippines to study the operations of their rural banking system. The Philippines was selected for the reason being that, it was one of the few countries which have successfully operated such banks on a reasonably large scale. More so, their stage of development was vital to ours. Rural Banks were first established in Ghana in 
1976 to provide banking services to the rural inhabitants, giving credit to small-scale farmers and businesses and supporting developmental projects in rural communities. In 2002, one hundred and fifteen (115) rural banks had been established and they were supervised by the clearing bank ARB Apex Bank under the regulation of the bank of Ghana which owns shares in the banks (Tsamenyi \& Shazad, 2008).

In trying to serve this community efficiently and effectively, there is the need for these Rural Banks to introduce ICT in its operations and management so as to achieve this goal since this modern age has to do with ICT. The role of technology in the "Information Age" is well recognized by the business, industry, and government and is completely woven into their organizational structures and strategic planning processes. Furthermore, the integration of strategies, organizational structures and business processes by the use of specialized information technology is considered a vital part of performance management concept. Additionally, the important element of management is information processing and thus information technology systems are expected to heavily influence banking management.

\subsubsection{Rural Banks Management in Ghana}

As in other Sub-Saharan nations, Ghana has traditionally had a series of setbacks such as low-income levels, low domestic savings, low productivity, unemployment, just to mention a few. It is by this that, in 1976, the government of Ghana through the BOG established rural banks to provide credit to productive rural ventures and facilitate rural development. Thus, rural development is a strategy intended to improve the quality of life and economic well-being of people living in relatively isolated and sparsely populated areas. The government of Ghana in June 2006 published its second growth and poverty reduction strategy (GPRS II) for the time period of 2006 to 2009. The GPRS II is directed by the goal of doubling the size of the economy within the decade and bringing the average per capita income of Ghanaians to middle-income country level by 2015 . Henceforth, this Annual Progress Report (APR) is the first assessment of progress done in the implementation of policies defined in the growth and poverty reduction strategy (GPRS II) and cover progress in 2006. So, with the establishment of rural banks as well as the introduction of ICT in its operations, management are expected to put in more effort to get the best results in the next assessment on the (GPRS) by the (APR).

\subsubsection{Functions of Rural Banks}

Rural banks have the mandate to undertake the business of banking following by the limitation and the manner provided for in the banking act 5. It has the following as it cores mandate or functions;

1) Offering financial advice to its customers and others in rural areas. Banking Act 1970 (Act 339).

2) To offer credit facilities to small scale farmers, fishermen and other economically active people in the rural areas. 
3) It renders funds management services.

4) It Develops credit assessment procedures and monitors loans and advances.

5) It gives cash and receives excess cash.

6) It identifies viable industries in their respective catchment areas for investment and development.

7) To mobilize resources locked up in the rural areas into banking systems to facilitate development.

\subsection{Statement of the Problem}

There have been series of problems and limitations associated with the manual system of banking as seen over the decades in banks some years past, internet or electronic banking is currently used in almost all the banks in Ghana. Notwithstanding, there is less firsthand information with regard to the extent of adaptation of Information and Communication Technology, its bad or good impact on rural banks, its importance to both clients and the bank as well as the challenges it brings to the banks and its clients or customers. The banking sector in Ghana has seen great changes linked with the developments in ICT in recent years. The desire to live, global benefits, maintenance of existing market share and sustainable advancement has made exploitation of the many benefits of ICT through the use of automated devices vital in the industry or sector.

Thus, the purpose of this study is to examine the impact on Ghanaian Rural Banks Management using ICT as a tool in the banking sector, evaluate the degree at which they have taken and deployed innovative technologies and analyze the resultant impacts of these technologies in their operations or duties.

\subsection{Research Objectives}

This work aims at addressing a particular objective in developing the investigation for further analysis. Henceforth, below are the objectives of the study;

First of all, it seeks to identify the benefits of introducing Information and Communication Technology. As a matter of factor, everyone is aware of the numerous benefits of ICT in our daily life activities. And so, for life to be easy, there is, therefore, the need to introduce ICT in the rural banks to help educate both literate and illiterate to help make the process of banking easier, faster, and efficient.

More so, know the mode of operation before and after the introduction of Information and Communication Technology (ICT). This will, in turn, help the rural banks to compare and contrast the results with regards to the introduction of ICT in its operational management.

Finally, it seeks to look out for the challenges of introducing Information and Communication Technologies (ICT). Every enterprise looks for success when trying something new in its organization or firm. Also, one tries to find out the problems that face a specific thing introduced and the way it can help bring the organization to the light. 


\subsection{Research Questions}

In reference to the background information given to the problem, stated questions will be answered and addressed.

How was the mode of visitation before and after the introduction of Information and Communication Technology (ICT) in rural banks? Has ICT impacted the mode of visitation negatively or positively when it comes to making a comparison between the years back and this modern time?

Any new thing introduced has some problems or challenges. Hence, the researcher tries to look at the challenges which have affected ICT in banking since its introduction. What are the challenges of introducing ICT in rural banks?

There is no doubt that ICT has numerous positive benefits as against the negative ones which of course makes banking transactions far easier, faster and straightforward for customers. Notwithstanding, it looks like most customers do not know the importance of ICT in rural banking. Do customers know the importance of ICT?

\subsection{Significance of the Study}

\subsubsection{Theoretical Significance}

A comprehension of the use of Information and Communication Technology in rural banking management is key in enhancing customer satisfaction; it is argued that studies on ICT and bank operations management are needed. Notwithstanding, the rapid developing impacts of ICT in rural banks have been ignored, and also limited research has been done on bank penetration. Previous studies of ICT adoption have mostly been based on other commercial banks, henceforth, the recent research attempt to fill the theoretical gap and this research are of good assistance to the management of Atiwa rural bank and other related banks to enhance upon their ICT usage to facilitate customer needs and satisfaction.

\subsubsection{Practical Significance}

It is emphatically clear that ICT advancement helps payments and also creates options for cash and cheque for making banking transactions. This new practice has brought the development of a truly global, seamless and internet-enabled 24-hours banking. ICT advance in payments is of benefit for the reason being that it is possible and practical to outsource quite a number of the bank's duties in the payment system. Moreover, rural banks' regulation can be more technologically dependent and better concentrated rather than concentrating on theoretical or conceptual guidelines. With regards to practical significance (Akinuli, 1999), said, ICT revolution both in terms of innovation rate, speedy operation, and cost per unit (portraying reduction in average total and marginal costs) has made a good number of banks embrace the use of ICT infrastructure in their operations. But there may be some little challenges at a time because of network failures, which of course may hinder a customer from carrying out transactions at a point in time yet this little problem can not in any way compare to the years 
back when banking halls were characterized by long queue because of delays in the traditional banking operations.

An understanding of these practical significances of the adoption of ICT in rural banks helps management to put in measures to ensure that the ICT infrastructures are always in good shape and maintained to ensure quality customer service, delivery, and satisfaction as well as efficiency in its operations.

\section{Literature Review}

\subsection{Theoretical Review}

In the previous decade, there has been a strenuous effort towards automation in Ghana due to the speedy improvement of Information and Communication Technology (ICT). Agreeing to Nayak et al. (2010), ICT can be understood as "technologies that facilitate communication and the processing and transmission of information by electronic means". Hence, Gupta \& Yadav (2017) meant to focus on the customer's perception of technology being used for delivery of financial products and services and how the customers can understand the effect of ICT in our daily life. Computers have offered organizations with different means to their transactions, accounting, payment and personnel management undertakings. Computerization is the foundation on which the prospect of the Ghanaian economy, especially the financial segment is being designed. Computerization of the activities of banking establishments is thus the standard of the day, international. Unlike commercial banks, rural and community banks halt late with respect to the usage of such technology, precisely computers, and networking. Rural banking is the means of managing banking transactions out in the nation where bank offices are too distant away to be of use. Thus, Rural banking is common for small towns and farmers who live far away from areas of the more expensive populace and cannot make the effort to these places whenever they want to use banking facilities. Normally, a representative of the bank will visit these rural zones and bid to make transactions in an authorized ability (Ampah, 2010). Rural banks in Ghana have been given the main obligation of offering banking services to rural and community Peoples. These services comprise banking and generating interest for funds deposited, making loans available to qualify rural people especially those in agri-businesses, petty trading and small-scale manufacturing (Bank of Ghana, 2004). According to Basweti et al. (2013) investigated the effects and challenges of ICT adoption in the banks. Their report establishes that there is a requirement for bankers to teach the public in the usage of online banking goods, invest more in ICT infrastructure and the government to decrease the duties of ICT devices. In modern eras, the dynamism within the Ghanaian banking industry has created high levels of competition (Buchs \& Mathisen, 2003). Nevertheless, irrespective of the improvement in ICT, much of the functions of the rural banks are still undertaken manually. This problem has thereby reduced their competitive superiority in the industry. It has, thus become common to see the giant commercial banks increase their 
activities to cover target markets reserved for rural banks to increase their client base, thus bringing strong competition to the rural banks. Information and Communication Technology has widened the scope of banking practices and changed the nature of banking as well as the competitive atmosphere in which they operate. A comprehensive opening has been experienced around the world for banks and they are presently taking proper advantage of these innovations to provide improved customer services in the face of competition and faster services that enhance productivity (Akinuli, 1999; Ovia, 2005).

\subsection{Empirical Studies.}

Managers cannot overlook Information Systems because they play a crucial part in the modern organization. The application of information and communication technology ideas, techniques, policies and implementation strategies to banking services has become a topic of basic significance and concerns to all banks and truly a requirement for native and worldwide competitiveness. ICT directly affects how managers choose, how they plan and what products and services are presented in the banking industry. It has persistent to change the way banks and their corporate relationships are structured global and the variation of innovative devices available to improve the speediness and quality of service delivery.

And so, for the rural banks to be able to compete well, they have to enhance their services by improving upon their technical infrastructure and human resources. Alabar \& Agema (2014) examined the impact of ICT on customer satisfaction in the Nigerian banking industry. The report adopts an empirical approach in determining the relationship that occurs between the present state of ICT and customer contentment in the industry. The following suggestions were henceforth made banks should repeatedly study the possibility of raising the standard of ICT based systems and services, strengthen efforts in meeting up with international operational systems and prove a high sense of reliability, responsiveness, and reliability in the application of ICT in their operations. More so, the rural and community banks need to be officially joined into normal banking services. By regulation, they have to be able to comply with the Central Bank of Ghana's policies of cheque clearing and management information report sending. These requirements led to the formation of the Association of Rural Banks (ARB) and later the ARB Apex Bank Ltd (Addeah, 1989; Agyei, 2001; Steel \& Andah 2003).

Again, another researcher by name Amaoko (2012) contributed positively to the provision of banking services and the growth of the Ghanaian banking industry through ICT. Morufu \& Taibat (2012) researched banker's perception of electronic banking in Nigeria purposely to find out how bankers see the profits and threats associated with electronic banking by examining bank employees' perceptions of electronic banking and its consequences on bank service delivery. At the end of the study, Morufu et al. came to the deduction that electronic banking and ICT as a whole play a key role in the banking industry and this as- 
sists the banking industry to develop. Amaoko (2012) in his study on the impact of ICT on banking operations in Ghana, ICT has contributed positively to the delivery of banking services and the progress of the Ghanaian banking industry. Internet banking and on-line banking is not yet developed in Ghana. The study suggested that banks should develop user-friendly systems and applications for the general population. Hence, the government and banks should play a vital role in improving ICT infrastructure, put in place incentives like tax reduction, make computers (PC) available and cheap for every Ghanaian. A study about employee perception towards technology in banking sector found that the bank employees feel that the management plays an important role in promoting the adoption of technology at the workplace and the factors, such as training, employee learning, management support, and coordination play an important role in positively orientating the employees towards technology at the workplace.

All these empirical studies put forth by the various researchers point to the fact that indeed ICT cannot be overlooked as much as development in the banking industry is a concern and therefore recommend that rural banks should adopt ICT in its operations to ensure rapid progress and quality customer delivery.

\subsection{Rural Banks Management in Ghana}

As in other Sub-Saharan nations, Ghana has traditionally had a series of setbacks such as low-income levels, low domestic savings, low productivity, unemployment, just to mention a few. It is by this that, in 1976, the government of Ghana through the BOG established rural banks to provide credit to productive rural ventures and facilitate rural development. Thus, rural development is a strategy intended to improve the quality of life and economic well-being of people living in relatively isolated and sparsely populated areas. The government of Ghana in June 2006 published its second growth and poverty reduction strategy (GPRS II) for the time period of 2006 to 2009. The GPRS II is directed by the goal of doubling the size of the economy within the decade and bringing the average per capita income of Ghanaians to the middle-income country level by 2015. Henceforth, this Annual Progress Report (APR) is the first assessment of progress done in the implementation of policies defined in the growth and poverty reduction strategy (GPRS II) and cover progress in 2006. So, with the establishment of rural banks as well as the introduction of ICT in its operations, management are expected to put in more effort to get the best results in the next assessment on the (GPRS) by the (APR).

\subsection{Impact of ICT on Rural Banks' Financial Performance}

Fundamentally, all the traditional banks in Ghana are spending huge sums of money in gaining of ICT equipment, networking their various branches and employing IT personnel to manage them. These coupled with the huge cost of training staff to use this IT equipment negatively affect the balance sheet of the 
banks in the short run. And so, these traditional banks acquire several ATMs, Computers, and very expensive software, issuing of electronic cards, and the rest, all at a cost to the banks.

Rural banks in Ghana have lately embraced the computerization of their businesses like these traditional banks. Henceforth, it has become needed to find out whether ICT impact positively on the performance of these rural banks to merit the cost related to it. Most of the managers of the several rural banks in Ghana are now thinking of adopting ICT for their daily operations. The question now is; what is the impact of ICT on the mobilization of deposits in the rural banks? Is there a meaningful relationship between ICT usage and the profitability of rural banks? Has ICT usage any impact on the credit administration of the rural banks? The main objective of this study is to assess the impact of the use of ICT on rural bank management. The specific objectives are; to examine the impact of ICT on the mobilization of deposits; to evaluate the impact of computerization on the recovery of loans; to examine the impact of computerization on the profitability of the rural banks. The study focuses on the impact of ICT on rural bank management as perceived by the staff and management as a result of the adoption of ICT.

In general, current studies have established two positive impacts regarding the relationship between ICT and rural banks' financial performance; Firstly, ICT can reduce banks' operational costs (the cost advantage). Secondly, ICT can facilitate transactions among customers within the same network (the network effect) (Farrell \& Saloner, 1985; Katz \& Shapiro, 1985; Economides \& Salop, 1992). Truly, Saloner and Shepard, using data for United States commercial banks for the period 1971-1979, showed that the concern of network effect is important in the ATM adoption of United States commercial banks and this was also backed by Milne (2006). Likewise, some studies are agreeing with the positive impact of ICT spending to business value. Kozak (2005) assesses the impact of the progress in ICT on the profit and cost efficiencies of the US banking sector during the period of 1992-2003. The study shows a positive correlation between the levels of implemented ICT and both profitability and cost savings. More so, a research carried out by Maldeni \& Jayasena (2009) also approves a positive linear relationship between ICT usage and bank's performance (deposit mobilization, loan recovery and profit). Shu \& Strassmann (2005) studied 12 banks operating in the US from 1989 through 1997 and discovered that although ICT has been one of the most marginal productive factors among all inputs, it cannot increase banks' profits. A study done by Maldeni \& Jayasena (2009), assessed the impact of ICT on bank branch performance. They explained that ICT usage at the bank branch involves three elements; ICT application, ICT literacy of staff and customers, and attitude of staff and customers towards ICT. They used Pearson's correlation coefficient to measure the linear relationship between variables. The analysis showed that ICT usage has a positive linear relationship with financial performance and quality performance of bank branches.

From the several empirical studies conducted, it could be seen that truly ICT 
has a positive impact on the financial performance of rural banks and could be measured as significantly high.

\subsection{Relationship between the Bank Performance before and after the Training}

I indeed, the success of any work is normally stated in terms of meeting three major objectives: completion on time, completion within budget, completion at the desired level of quality or technical specification (Tukel \& Rom, 2001; Xiao \& Proverbs, 2003).

The background of this study is the adoption of ICT has influenced the content and quality of banking operations and staff performance even before and after receiving training. From all indications, ICT gives great potential for business process reengineering of Ghanaian Banks. Thus, investment in information and communication technology should form an important part of the overall strategy of banking operators to guarantee effective performance. It is therefore imperative for bank management to strengthen investment in ICT products to enable speed, convenience, and accurate services, or else lose out to their competitors.

It is in this view that banks have spent millions of Cedis in organizing training back-up on ICT every year in a bid to fully automate operations and services to customers. The sector acknowledged that ICT was a major key to its development. Furthermore, as a result of the improved demand for deposits, Ghanaian rural banks have recognized the imperative of good and prompt customer services. Besides, since some clients lost their deposits in the previous technicallyinsolvent banks, they have now understood that one way in which they can offer quality service is through the use of information and communication technology (ICT). Therefore, there is a growing rate of adopting new technologies in Ghanaian banking operations which in one way or the other has helped the banks' performance as compared to the previous decades when ICT was not in place. There is no doubt that, this has brought to light, the fact that ICT has boosted competition within the industry than before. The awareness that the market size is not actually increasing, has made banks more competitive. Similarly, the anticipation of their customers is extremely high and in response, banks are using ICT to satisfy the demand for quality services and products by customers hence the need to frequently organize training back-up for stakeholders in other to achieve higher performance than previously. As a result of attaching their operations on computer-based delivery systems, the rural banks have become very profitable and also doing well in terms of performance especially as the day in day out, stakeholders receive training to abreast themselves to meet this computer age era. They have introduced combined banking systems using WANs (Wide Area Networks), hence, their customers no longer have to carry cash for a long distance. Atiwa Rural Bank Limited is a good example of banks that have incorporated online, real-time banking systems. 


\subsection{Challenges of Rural Banks Management}

From the time of its assessment, rural bank management has been affected by their exceptional functioning, financial problems, and challenges that have inhibited progress and undermined the performance of its core functionality. In light of this, the Bank of Ghana removed the banking license of twenty- three (23) suffering rural banks in 1993/1994, another twenty-three (23) more rural banks in 1999/2000 and three (3) other rural banks in 2008/2009 (Asiedu-Mante, 2011). A study by Asiedu-Mante (2011) states the most pronounced of these suffering as those relating to liquidity, inadequate staffing, weak management, low capitalization, lousy loan recovery and profitability, ineffective internal control and inadequate technology. He also generally groups the problems into four categories:

1) Institutional Factors

2) Economic and Political Factors

3) Regulatory and Supervisory Factors

4) Fraudulent Factors

Nevertheless, Asiedu-Mante failed to admit the greater threat of providing credit to rural individuals and businesses which is not compensated for through high-interest charges. But, Credit facilities to enhance agricultural projects in rural areas are usually at the mercies of the weather and other natural occurrences. Again, the economic activities in a local community might not be enough to help the full operations of its regional rural bank. In as much as rural banks make innovative solutions to the peculiar challenges they encounter in their services; further capital investments can permit them to diversify their operations to decrease risk and manage shocks. A research conducted by Nair \& Fissha (2010), gives several additional specific challenges and limiting framework of rural banks in Ghana. In their report, they drew several fundamental factors like the poor operating environments for most rural banks and capacity limitations, particularly concerning finance. Their research work on rural banks in Ghana shows that the condition of location-specific ownership enforced on rural banks is a major disadvantage to the growth and network of rural banks. Also, profits from scale economies, teamwork, better managerial and operational performance in the sector are thereby lost. Furthermore, rural banks are also confronted with the challenge of inappropriate keeping of records, particularly the shares list that is crucial to association activities. These and other many underlying problems and challenges in the structure of rural banks in Ghana, make association policies and choose a challenge in the rural banking division.

\section{Research Methodology}

\subsection{Research Design}

The research design for the study is an exploratory study. Thus, is a valuable means of finding out what is happening to get new understanding; to ask questions and assess occurrences in a new light. Hence, it is carried out when a re- 
searcher wants to explore areas about which he or she has little or no knowledge. One of the benefits of exploratory research is that it is flexible and adaptable to change.

Basically, the form of research question decides the research approach to use. In this case, the case study strategy is adopted as the most suitable research strategy because the research questions about this study are "how" or "why" questions which make the case study more suitable than a survey or an archival analysis.

Again, the research approach in this study is selected based on the purpose and the research questions set out to be addressed. So, in exploratory research such as this, a qualitative approach will be adopted. Qualitative data are characterized by richness and fullness based on the chance to explore a subject. The kind of qualitative study is mainly to understand, not to explain. Therefore, qualitative research involves an emphasis on processes and meanings that are not measured regarding quantity, intensity or frequency. The main characteristics of qualitative research approaches have been described by (Miles \& Huberman, 1994) as shown below

1) The aim of qualitative analysis is a complete detailed description

2) It is recommended during earlier phases of research projects.

3) The design emerges as the study unfolds.

4) The data is in the form of words.

The researcher adopted the qualitative approach to the study since he wanted to have a greater understanding of the impacts of ICT in rural bank management. The population is an important group of people under investigation for the study and it comprises of the entire individuals and objects of interest or measurement obtained from all individuals. According to Malhotra \& Singh (2007), the population is the aggregate of all elements, sharing some common set of characteristics that involves the universe for the research problem. Thus, the population for the study is made up of the highest-level management, intermediate and lower-level management workers, and customers of Atiwa Rural Bank Limited in Ghana, West Africa. Henceforth, the research is limited to Atiwa (Anyinam) Branch of Atiwa Rural Bank Limited. Altogether, three hundred (300) respondents were sampled, consisting of the following groups of people shown in Table 1.

1) Two hundred (200) customers were chosen at random from Atiwa to ask for their opinions and feelings about the effects of information, communication, and technology on banking performance.

Table 1. The sample of respondents.

\begin{tabular}{cc}
\hline RESPONDENTS & TOTAL \\
\hline Highest Level Managers & 10 \\
Intermediate and Lower Level Workers & 90 \\
Customers & 200 \\
TOTAL & 300 \\
\hline
\end{tabular}


2) Ninety (90) intermediate and lower-level workers of Atiwa Rural Bank limited in the area of study, to find out from them their opinions and views on the impact of the computer on their performance.

3) Ten (10) top managers were chosen from the branch of the bank to find out their opinions on the impact of the computer on their performance and whether they have strategies for improvement in the future.

Different sampling methods were used for multiple respondents. And so, for the customers, random sampling was selected. Thus, this sampling procedure guarantees that each case in the population has uniform chances of being included. This specific sampling method was used because it was found easier to conduct and assess. Again, convenient sampling or haphazard sampling was picked for the intermediate and lower-level workers. It is because that one is simply available to the researcher by its availability that it involves haphazardly those situations that are simplest to get for our sample. This sample was chosen because the researcher got all or almost all the questionnaires back, so there was a good response rate. The study used primary sources of data.

The primary data is the data gained directly from a source that was examined and recorded by the researcher at the time it was taken. Hence, the primary data in this research were taken from the questionnaires given to the respondents. But the secondary data were collected through the internet, journals, and reports.

The researcher used the structured method to get suitable information needed to meet the goals of this study. This made use of structured questionnaires. The questionnaire was the key research instrument used in collecting the data for the study to achieve particular objectives and taking into consideration the sample size. For an easy understanding and reading, the questionnaires were structured into three parts.

Firstly, the questionnaires for the customers contained closed and open-ended statements to ask personal information. Open-ended questionnaire was used to allow respondents answer in open text format such that they can answer based on their complete knowledge, feeling, and understanding. It also intends to attain detailed and descriptive information on a subject (respondents). Closed-ended questionnaire were used to allow respondents to choose from a distinct set of pre-define responses, such as "yes/no" or among set multiples choice questions. it is also intended to gather quantitative data from respondents. Also, Section B is made up of five (5) items of closed and open-ended statements. Responses to feeling, views, opinions, and attitudes were used to make submissions.

Secondly, the questionnaire for the intermediate and low-level workers is in two (2) divisions. Section A contains five (5) closed-ended statements to ask personal information, while section B is made up of ten (10) open and closed-ended statements to seek information concerning the feeling, views, opinions, and attitudes and to make submissions.

Furthermore, the third questionnaire was for the highest-level management and is made up of (15) items of closed and open-ended statements in two parts. 
Part A contains five (5) Items to enquire personal information in relation while part B is made up of ten (10) open and closed-ended statements to ask information about feeling, views, opinions, and attitudes concerning the impact of the computer on banking as well as to submit.

\subsection{Data Collection Method}

This chapter is organized around the research questions in chapter one. This chapter presents a brief analysis of data along with a discussion of each research question with corresponding statistical analysis. The objectives of the study were to be used by the researcher as a guide in analyzing the findings obtained from the fieldwork. This research work mainly focused on primary data.

A research instrument that were used was a survey, questionnaires, test, scale, rating or tool designed to measure the appreciated characteristics or information of interest, often a behavioral or psychological characteristic. For this research, I resorted to both questionnaires and interviews as means of soliciting information from the population as there were both literates and illiterates and as such the researcher on few occasions used interviews mainly on some customers.

In that situation, the respondents were interviewed face to face using the Asante Language and English to facilitate the full expression of feelings, views, opinions, and attitudes.

\section{Data Analysis and Discussion}

\subsection{Data Analysis}

Here, the data for the analysis was obtained from the survey. Hence, descriptive analysis was largely used for the analysis. To determine the impact of ICT on rural bank management, descriptive statistics were used in the analysis of the results. Also, the study used the Statistical Package for Social Sciences (SPSS) and Microsoft Excel program to produce the outcomes or results. Because this study is exploratory in nature, no thorough statistical technique was used in examining the data.

\section{Organizational Profile}

Atiwa Rural Bank Limited, where this centered case study, is one of the leading impressive rural banks in the Eastern region of Ghana and it was named after the district within which it is situated-(Atiwa East District). The Atiwa East District is one of the naturally gifted districts which are mainly made up of numerous communities with farming as their main livelihood. The Atiwa Rural bank was included as a Limited Liability Company under the companies' code, Act 179 of 1963 in January 2000 and it was licensed to begin a business in June 2001. It has its Head Office at Atiwa Kwabeng in the Eastern region of the Bunso to Nkawkaw road and about twenty-five (25) kilometers from Anyinam shown in Figure 1. Credit share capital, loans, investment, and assets had since in 2002 improved very considerably. From the initial staff of five (5), the bank now gives employment to about a hundred staff, fifty-five (55) mobile bankers, and thirty 


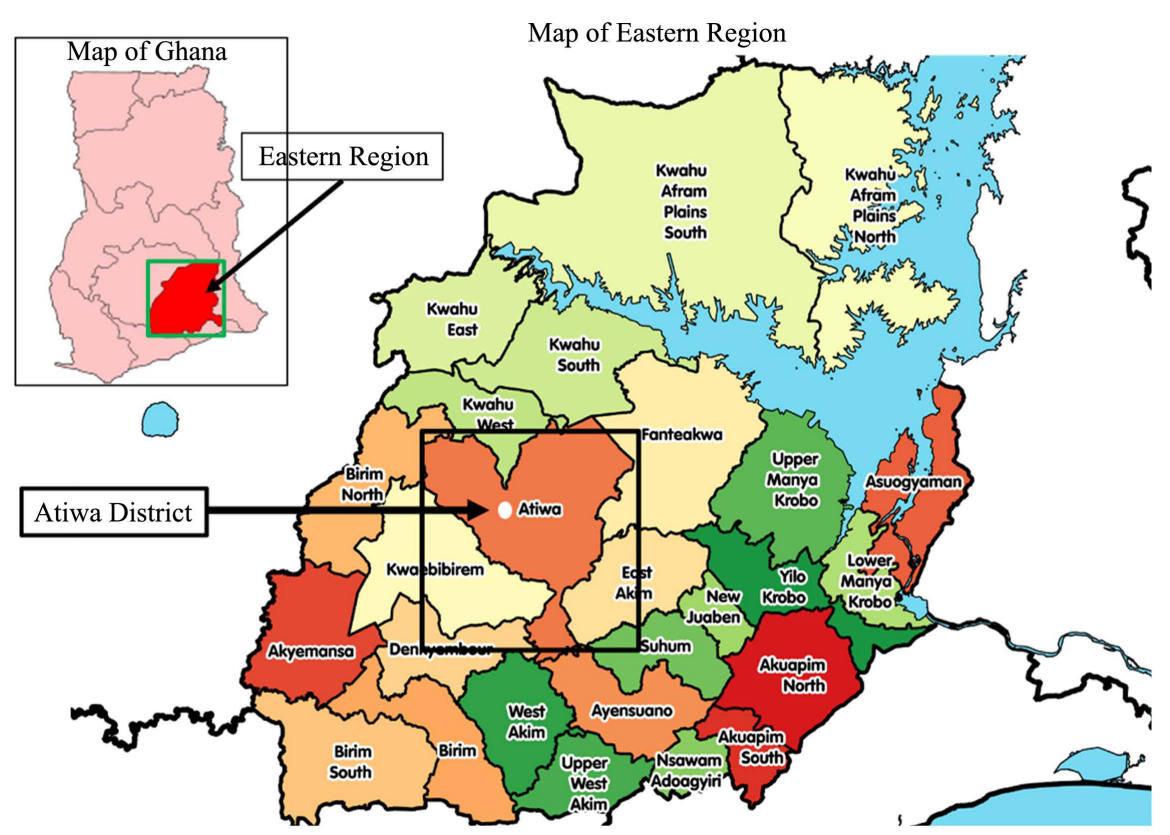

Figure 1. Map location of Atiwa Rural Bank.

(30) security staff. Additionally, the bank can also claim of eleven (11) branches in addition to its Head Office at AtiwaKwabeng.

\subsection{Discussion of Results}

\subsubsection{Socio-Demographic Data}

The socio-demographics-demographics data was taken to know the personal information of respondents which was useful in understanding their satisfaction with the bank's ICT innovation. Therefore, the areas covered included gender of respondent, the age distribution, marital status, and educational level.

\subsubsection{Gender of Respondents}

The results as specified by Figure 2 depicts that, out of the three hundred (300) respondents, one hundred and forty-four (144) were males representing (48\%) whereas One hundred and fifty-six (156) were females representing (52\%) which shows the total representation by both sexes at the branch.

\subsubsection{Age of Respondent}

The age of respondents ranged from 20 - 35, 36 - 45, and 46 - 55. Table 2 shows that the majority of the respondents fell within the range of $20-35$ which represents the total sample size.

\subsubsection{Type of Job Respondents}

The respondents who answered the questionnaires can be categorized into three groups, namely: Unskilled or semi-skilled workers, trained office workers, and vocationally trained craftsperson. A total number of one hundred and thirty-one (131) representing forty-three percent (43\%) are unskilled or semi-skilled workers while a total number of ninety-two (92) representing thirty-one percent 


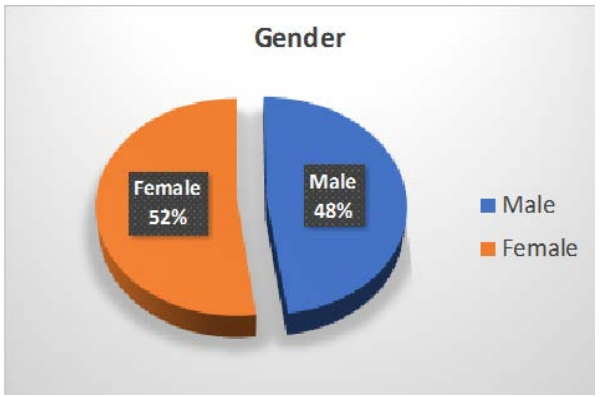

Figure 2. Gender of respondents. Source: Field survey (2020).

Table 2. Age of respondent.

\begin{tabular}{ccc}
\hline RESPONSE & FREQUENCY & PERCENTAGE \\
\hline $20-35$ & 113 & $37 \%$ \\
$36-45$ & 110 & $37 \%$ \\
$46-55$ & 77 & $26 \%$ \\
TOTAL & 300 & $100 \%$ \\
\hline
\end{tabular}

Source: Field survey (2020).

(31\%) are trained office workers. On the other hand, seventy-seven (77) respondents are vocationally trained craftsperson representing twenty-six percent (26\%). Figure 3 below gives the detail information on the type of job respondents

\subsubsection{Educational Level of Respondents}

The BECE/WASSCE certificate holders from Table 3 and Figure 4 below representing $49 \%$ were majority which clearly shows that the bank is not for the elite only but thus open to all especially farmers, traders, businessmen, and women, no matter the educational level. They were followed by the diploma holders with $28 \%$, degree holders with $17 \%$ and $6 \%$ representing those with a postgraduate degree.

As explained earlier, the above table and figure depict the details of the educational level of the respondents.

\subsection{Hours (Time) Spent at the Bank}

Responding to how the bank was strategically using ICT in its operations, 100\% of the management staff respondents said they apply ICT to shorten customers' waiting time. Ninety-two (92\%) of the other staff members of the bank strongly agreed that they used ICT to transact fast business with customers and with $98 \%$ of the customer respondents strongly agreeing that less waiting time in the banking hall was the basis of the attraction of the bank to them. Again, a further $98 \%$ of the customers stated that the less waiting time they spent in the banking hall provided them satisfaction to continue to transact business with the bank. Nonetheless, two (2) of the customers also stated that the hours spent at the bank have not reduced with reasons that power and network failure sometimes 

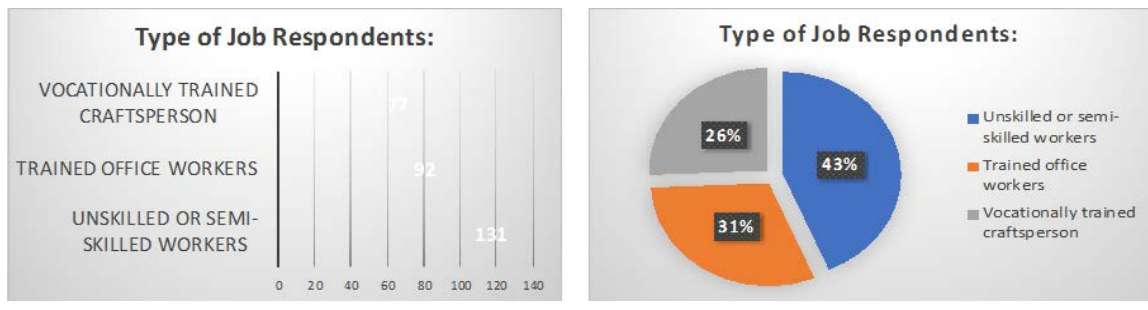

Figure 3. Type of job respondents. Source: Field survey (2020).
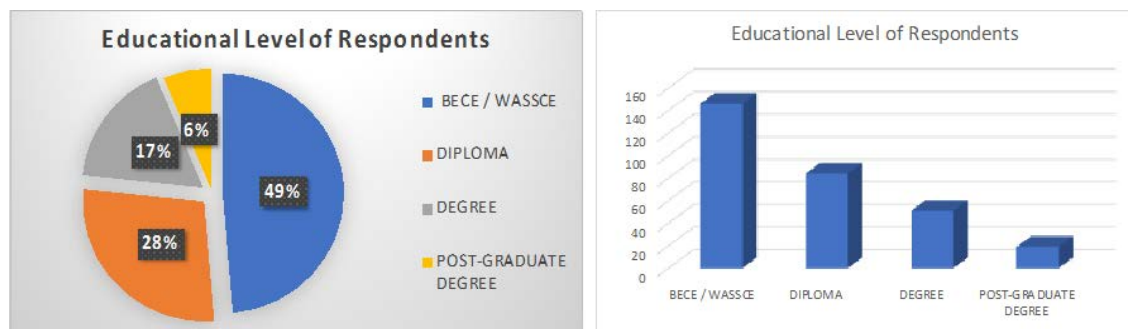

Figure 4. Educational level of respondents. Source: Field survey (2020).

Table 3. Educational level of respondents.

\begin{tabular}{ccc}
\hline RESPONSE & FREQUENCY & PERCENTAGE \\
\hline BECE/WASSCE & 146 & $49 \%$ \\
DIPLOMA & 84 & $28 \%$ \\
DEGREE & 51 & $17 \%$ \\
POST-GRADUATE DEGREE & 19 & $6 \%$ \\
TOTAL & 300 & $100 \%$ \\
\hline
\end{tabular}

keep them waiting. Therefore, this implies that Atiwa rural Bank should focus its efforts on those areas' customers feel are most important such as timeliness. They are shown in Figure 5 below.

\subsection{Awareness of the Importance of ICT in Rural Banks Management and Efficiency in Computer Usage (Workers)}

When the respondents were asked whether they were aware of the importance they could derive from Internet banking, 75\% of them said they were aware of the importance of Information, Communication and Technology whilst $25 \%$ did not know the benefits Internet banking offered in the rural banks. But, the respondents who appear to know the importance of Internet banking also recommended to the company that is made available by the bank, because of the importance of Internet banking such as making business transactions easy and faster, saving time and cost, allowing for fast access to daily bank balances, and enhancing communication. Nevertheless, about $90 \%$ of those who were not aware of the benefits of Internet banking said they would not recommend it to their banks whereas $10 \%$ said they would, however, recommend it to their bank. Security concerns were the major reason cited for their decision not to recommend internet banking to their banks. So, this implies that most customers are 
Managements staff response on the use of ICT in its operations (i.e time factor)

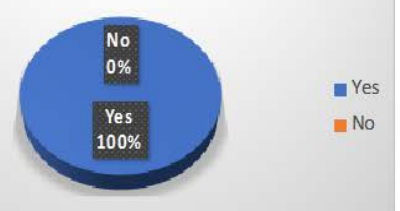

Staff Members

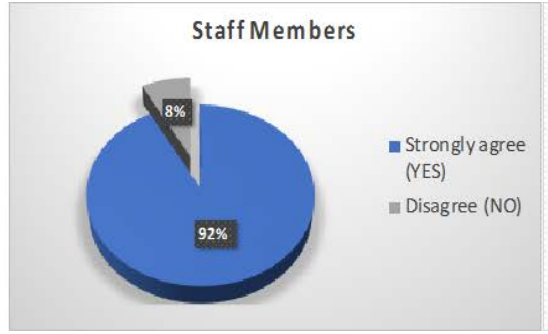

Hours(time) spent at the bank (Customers)

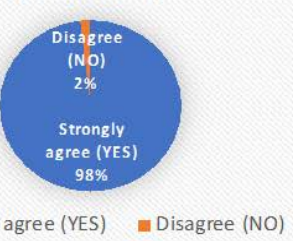

Figure 5. Below depicts the overview of the above information concerning the hours (time) spent at the bank. Source: Field survey (2020).

familiar with the basic importance of ICT in the bank and hence expects that these new technologies will be user friendly.

Furthermore, in seeking information from customers concerning their views in the efficiency of workers of the banks, two hundred (200) respondents representing one hundred percent (100\%) expressed their satisfaction in the efficiency of the bank workers with the introduction of computers. On the other hand, zero (0) people representing zero percent $(0 \%)$ of the respondents were not satisfied with the efficiency of the workers. Surprisingly when asked, the reason was that, despite the few challenges associated with the introduction of computers, they are still satisfied with the efficiency of the workers. Again, the respondents said they are satisfied because the signature of top management had been installed on the computer thereby making the cashier process documents on time thus reducing the number of hours spent at the bank. Details of responses of customers on the issue of efficiency in the use of the computer by workers of their Bank are contained below in Figure 6.

\subsection{Discussion of Results}

\subsubsection{Research Question One (1)}

How was the mode of visitations before and after introducing Information and communication technologies (ICT) in rural banks? Has ICT affected the mode of visitation positively or negatively comparing the olden days to this modern era?

In response, the majority of the respondents said that they still visit the bank even though the bank implements more ICT related products. Out of the ten (10) management staff, $86 \%$ of them said they still visit the bank whereas $14 \%$ said they would not stop visiting the bank even after the bank started employing products such as Internet banking, Automated Teller Machines, E-Zwich, etc. Thus, the reasons they cited for visiting the banks ranged from cheque book collection, cash withdrawal, loan and facility negotiations, and cash deposit activities. This confirms the findings of previous researchers which have revealed that Internet banking users still do visit the bank branches. (Yakhlef, 2001) for example, thinks that one explanation for this is that, when customers have a problem or a difficult transaction to deal with, they would rather prefer a banking relationship built on human interaction and as such there will always be some need for traditional banking. 


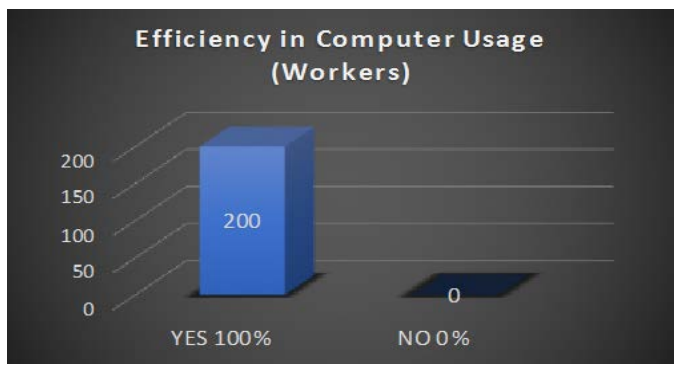

Figure 6. Efficiency in computer usage (workers). Source: Field survey (2020).

Hofstede (1985) considers Ghana as one of the countries with a low degree of individualism. Therefore, Ghanaians feel more relaxed with others and want to be connected to them. To be comfortable with others, cultures with a rich interpersonal communication consider face to face interaction to be essential as it consists of greater intensity thereof.

From the above results, it can be seen that ICT has not affected the mode of visitation to the bank negatively because the majority of the respondents said that they still visit the bank even though the bank implements more ICT related products.

\subsubsection{Research Question Two (2)}

Every new thing introduced has some challenges. Hence, the researcher tries to find out the challenges which have affected ICT in banking since its introduction. What are the problems of introducing Information and communication technologies (ICT) in rural banks?

In response to the question of future prospects of banking, one hundred and ninety (190) respondents representing ninety-five percent (95\%) expressed the view that the bank had a bright future. Some of the reasons were that, with the use of a computer, the bank could cope with the competition in the banking industry. So, computer technology will in the 21st century become a key to sustainable competitive advantage in Ghana. Another reason is that it will increase the number of customers of the bank shortly because transactions will be affected more quickly and efficiently because of computer networking. Whereas, ten (10) respondents representing five (5\%) percent also said that computerization does not affect the future of the bank, because as one respondent put it "computer is not flexible for example network failure refusing access to the computer" etc.

Again, in response to the question of challenges that the bank faces, most of the respondents answered that there are poor internet services, and power failure. And so, when one wants to engage in transactions, it becomes a problem.

Finally, on the question of the software being used by the bank, the staff mentioned Terminus 24, and others such as; Tally Accounting, Sage Pastel, Smart Bank, Quick Cash, and Quick Books.

Also, since its inspection, rural banks have been affected by their exceptional functioning, financial problems, and challenges that have inhibited growth and 
undermined the performance of its core functionality. Thus, the bank of Ghana has had to revoke the banking license of twenty-three (23) distressed rural banks in 1993/1994, another twenty-three (23) more rural banks in 1999/2000 and three (3) other rural banks in 2008/2009 (Asiedu-Mante, 2011). Asiedu-Mante (2011) states, the most pronounced of these distresses as those relating to liquidity, poor staffing, weak management, low capitalization, bad loan recovery and profitability, weak internal control and poor technology. He broadly classifies the problems into four (4) categories: Institutional Factors, Economic and Political Factors, Regulatory and Supervisory Factors and Fraudulent Factors

Nevertheless, Asiedu-Mante failed to acknowledge the higher risk of giving credit to rural individuals and businesses which is not compensated for through high- interest charges. Credit facilities to boost agricultural projects in rural areas are normally at the mercies of the weather and other natural occurrences. Again, much more than that, the economic activities in a local community may not be sufficient to support the broad operations of its local rural bank. Even as rural banks create innovative solutions to the particular challenges they face in their operations, additional capital investments can allow them to vary their operations to reduce risk and manage shocks.

Moreover, Nair \& Fissha (2010) offer some more specific challenges and preventive framework for rural banks in Ghana. In their work, they drew some causal factors like the poor operating environments for most rural banks and capacity constraints, especially in terms of finance. Again, their study on rural banks also in Ghana points out that, the requirement of location-specific ownership imposed on rural banks is a major weakness to the growth and network of rural banks. So, gains from scale economies, collaboration, better managerial and operational performance in the sector are thereby lost. Again, rural banks are also faced with the challenge of improper keeping of records, especially the shares list that is crucial to consolidation activities. Owing to the low level of literacy in the operating environments in which rural banks operate, stock certificates are kept as certificates of honors and are perceived as loan baits. These and many underlying problems and challenges in the structure of rural banks in Ghana make consolidation policies and options a challenge in the rural banking sector.

\subsubsection{Research Question Three (3)}

Information Communication and Technology (ICT) has more positive benefits as compared to the negative ones which make banking transactions for customers very simple and straightforward. But it seems most customers don't know the importance of ICT in rural banking. Are customers aware of the benefits of Information and communication technologies (ICT)?

The management of Atiwa rural banks understood that the introduction of ICT is a key strategic component in firm profitability. Hence, the importance of ICT and its effect on improving satisfaction and retention of customers, improving sales and market share, and improving corporate image could not be 
ignored. Therefore, the study showed that the inculcation of ICT in the bank's operation had an appreciable positive impact on customer service. Information, Communication, and Technology are now thought to hold the promise of a new commercial revolution by offering an inexpensive and direct way to exchange information and to sell or buy products and services. It was found that most customers of Atiwa rural banks will still visit their bank regularly and find interaction with human tellers very important.

\section{Conclusions and Policy Implications}

\subsection{Some Conclusions}

The following conclusions were made after interactions were made with customers, intermediate and lower-level workers and management by the study conducted in the Anyinam Branch of the Atiwa Rural Bank.

Thus, the customers expressed their awareness of the importance of the bank (Atiwa Rural Bank) using computers. These assertions make it clear that the bank, Atiwa Rural Bank uses ICT in its operations and most of its customers are aware of its existence and importance.

Therefore, the analysis showed that higher numbers (51\%) of the customers of the bank are females while the least number (49\%) are males. The study showed that the females contributed a lot to the bank's operation than the males. This is so because the population of the traders and businesses in the country was mostly women as compared to the males only dominating in farming. So, the bank should put measures in place to motivate the males in these areas to transact more with them. Again, a greater number of the respondent (100\%) expressed their satisfaction with the efficiency of the workers of Atiwa Rural Bank. Nevertheless, some of the customers indicated that there is a need for modification and improvement in their operations. Henceforth, since all the customers expressed their satisfaction with the use of the computer by the bank, then the bank (Atiwa Rural Bank) should continue with its operations using computers. Yet, since some of the customers expressed some concerns about computer usage, the bank should improve upon their operation. And this can be done by introducing Automated Teller Machine (ATM) in other to enable customers to have access to the bank after banking hours and when there is a network failure.

Moreover, on the prospect of the bank, sixty-eight percent (68.0\%) of the customers expressed their views that the bank has a bright future in the area of timesaving and work effectively. But, eighteen percent (18\%) of the customers also said that the bank has a bright future in the area of the efficiency of the workers. Also, ninety-eight percent (98\%) of the customers expressed that fewer hours are spent at the bank with the introduction of computers and other machines since the employees do not have to cross-check through ledgers before they are served. However, the remaining two percent (2\%) of the customers claimed that more hours are spent at the bank especially when there are power and network failure. 
With regard to the attitude towards the use of computers, a hundred percent $(100 \%)$ of the managers interviewed indicated their happiness with the introduction of computers in the bank. On the other hand; a hundred percent $(100 \%)$ of the workers were also happy with the introduction of computers in the banks' operations. About the challenges of computerization, respondents identified that new software being introduced was more often a challenge. More so, another challenge according to respondents is power and network failure which sometimes makes their work difficult.

Concerning the impact of computers on the output, all workers representing a hundred percent $(100 \%)$ confirmed that there had been an impact of the introduction of ICT in the bank in the sense that the personal computer (PCs) allows workers to get customer information easily. Additionally, the customer-worker ratio had also increased relatively. On the efficiency of the computer usage, all the ten (10) managers interviewed representing a hundred percent (100\%) answered in affirmative indicating that computers have brought efficiency in the bank's operations.

All managers representing (100\%) shared their views that the major problem facing the banking industry, in general, is competitiveness.

However, the issues of capital and weak internal control play a major role in determining the performance and profitability of Rural Banks. With the technological advancement of the general banking industry in Ghana, there has been need for rural banks to adjust and build a costly infrastructure that will improve service delivery to their clients. Whereas the strong loyalty of community inhabitants to the banks has helped the performance of the banks, especially in their initial stages, it has compounded the challenges that are associated with raising additional capital. The fundamental challenge will be to provide a solution that will increase capital contributions to the Rural Banks and improve their control structures without affecting their underlying mission to serve the rural communities. One major option for rural and community banks to raise capital is through unions and procurements. Some of the Rural Banks are struggling to meet the new capital requirement of the Bank of Ghana which stands at GH 150,000 . Thus, unions and procurement can offer the sector economies of scale that will improve performance, efficiency, better control mechanisms as well as provide operating capital to expand the operations of the sector to other localities. However, the unique governance structure and organization of the sector poses a challenge to merger and acquisition activities. These include social factors like the importance of names in the sector, high illiteracy in the rural areas and among shareholders, managerial and directors' sentiments and the high cost of engaging in mergers and acquisitions relative to their operational capital. And so, if the option of unions and Procurements are implemented properly for the rural banking sector, the sector will become more competitive and efficient. This study concludes that though the Atiwa rural bank has limited technological tools in place, the bank has been able to strategically use the very few technologies it has as a strong competitive tool to cut down on customers' waiting time, attract 
customers, deliver fast and convenient transactions, cut down on its operation cost, support efficient management decision making process, increase its productivity and profit levels since the deployment of ICT into its operation.

On the whole, the study concludes that ICT has a strong positive impact on the bank's operations and therefore serves as a strategic tool to attain a competitive advantage in the banking industry in Ghana.

\subsection{Implications}

In examining the rural banking setting and the accessibility of investment capital, the study focused on the impact of ICT on rural bank management. Thus, rural banks have a major role to play in our national growth and rural area development. So, this study collected data from the relevant institution in the rural banking sector and some experts' opinion on findings ways of making the banks more competitive and viable.

First and foremost, because the results of the study showed that Atiwa rural bank, like other rural banks in the country, has very limited innovative technologies in place, against the background that the bank's operations have seen much improvement as a result of the few ICT tools it has deployed, the management of Atiwa rural bank should try to bring on board more innovative technologies to help the bank survive the current trend of competition in the banking industry so as to contribute its roles to the economic development of the nation.

Again, the outcomes of the study further indicated that although Atiwa rural bank has succeeded in strategically employing the few ICT tools it has installed, the technology is not very functional resulting in the occasional break down in service delivery to customers. And so, it is therefore recommended that the bank should take steps to consult experts on powerful tools that can support its technology to ensure efficient service delivery.

Furthermore, with the discovery that lack of funds and unsuitable policies were the main causes of the slow rate of technology diffusion in the rural banking sector, the study advocates that government should provide these banks with adequate funding to assist them to acquire the necessary technologies to support their operations and remain competitive.

More so, the study further recommends that the Bank of Ghana and the Apex Bank should formulate policies that give the rural banks a free hand to decide their fate on technology implementation issues since it was disclosed that these bodies want all rural banks to roll out same technological platform which might be unsuitable for some or too expensive for them to afford.

Moreover, the management of the rural banks should guarantee that they involve their workers in any technology implementation discussion to ensure system ownership by all those who are to ensure that the system works. Also, training support, top management commitment, and staff motivation should be looked at to ensure that the rural banking sector sees shortly in an accelerated 
deployment of ICT in the sector to make the sector more competitive.

Lastly, the study suggests that the adoption of ICT by the rural banks in the country has the potential of improving the performance of most rural banks as well as providing them enough capital to meet their operational and expansion needs. Hence, one way to boosts this phenomenon is through education, support, and sensitization. With regards to the high illiteracy rates that exist in most rural areas in Ghana, it is recommended that the Association of Rural Banks organize seminars, forums, and general educational activities to inform rural persons of the need for computerization, therefore training these people on how to use the ICT related products the rural banks offer especially shareholders and other stakeholders like the chiefs, customers, and others. This can be done at their Annual General Meetings, management meetings, board meetings, radio talks, and discussions, among other innovative ways.

\section{Funding}

This research received no external funding.

\section{Authors' Contribution}

Each author contributed equally to the research article. All authors have read and agreed to the published version of the manuscript.

\section{Conflicts of Interest}

The authors declare no conflicts of interest regarding the publication of this paper.

\section{References}

Addeah, K. (1989). An Introduction to the Law of Rural Banking in Ghana. Accra: Amantah Publications.

Agyei, S. A. (2001). Regulatory Framework of Rural Financial Institutions in Ghana. Draft Report for Ghana Micro-Finance Institutions Network (May).

Akinuli, O. M. (1999). Information Technology in Nigeria’s Banking Industry: Operational Applications, Problems and Future Challenges. CBN Bullion, 23, 71-75.

Alabar, T. T., \& Agema, R. J. (2014). Information and Communication Technology and Customers' Satisfaction in Nigerian Banking Industry. Journal of Advanced Management Sciences, 2, 333-338. https://doi.org/10.12720/joams.2.4.333-338

Amaoko, A. (2012). The Impact of Information Communication Technology (ICT) on Banking Operations in Ghana. International Journal of Business and Management Tomorrow, 2

Ampah, S. K. (2010). Rural Banks in Ghana Collapsing. The Ghana Journal. http://www.theghanaianjournal.com/

Asiedu-Mante, E. (2011). Rural Banking in Ghana. Accra: Combert.

Bank of Ghana (2004) Bank of Ghana, Annual Report 2004. https://www.bog.gov.gh/

Basweti, O. K., Masese, C. B., \& Onsiro, M. R. (2013). Impact and Challenges of Information Communication Technology Adoption in the Tanzanian Banking Sector. Interna- 
tional Journal of Academic Research in Business and Social Sciences, 3, 323.

Buchs, T., \& Mathisen, J. (2003). Banking Competition and Efficiency in Ghana.

Economides, N., \& Salop, S. C. (1992). Competition and Integration among Complements, and Network Market Structure. The Journal of Industrial Economics, 40, 105-123. https://doi.org/10.2307/2950629

Farrell, J., \& Saloner, G. (1985). Standardization, Compatibility and Innovation. RAND Journal of Economics, 16, 70-83. https://doi.org/10.2307/2555589

Gupta, S., \& Yadav, A. (2017). The Impact of Electronic Banking and Information Technology on the Employees of Banking Sector. Management and Labor Studies, 42, 379-387. https://doi.org/10.1177/2393957517736457

Guru, B. K., Vaithilingam, S., Ismail, N., \& Prasad, R. (2001). Electronic Banking in Malaysia: A Note on Evolution of Services and Consumer Reactions. Journal of Electronic Bankinh, 48, 49-61. https://doi.org/10.1007/978-3-322-86627-1 15

Hofstede, G. (1985) The Interaction between National and Organizational Value Systems[1]. Journal of Management Studies, 22, 347-357. https://doi.org/10.1111/j.1467-6486.1985.tb00001.x

Katz, M., \& Shapiro, C. (1985). Network Externalities, Competition, and Compatibility. The American Economic Review, 75, 424-440.

Kettinger, W., Teng, J., \& Guha, S. (1997). Business Process Change.

Kozak, S. (2005). The Role of Information Technology in the Profit and Cost Efficiency Improvements of the Banking Sector. Journal of Academy of Business and Economics.

Laudon, D. P. and Laudon J. P. (2001) Management Information Systems: Organization and Technology in the Network Enterprise (4th ed.). Prentice Hall International in USA.

Maldeni, H., \& Jayasena, S. (2009). Information and Communication Technology Usage and Bank Branch Performance. International Journal on Advances in ICT for Emerging Regions, 2, 29-37. https://doi.org/10.4038/icter.v2i2.1386

Malhotra, P., \& Singh, B. (2007). Determinants of Internet Banking Adoption by Banks in India. Internet Research, 17, 323-339. https://doi.org/10.1108/10662240710758957

Miles, M., \& Huberman, M. A. (1994). Qualitative Data Analysis: An Expanded Source Book (2nd ed.). Thousand Oaks, CA: Sage Publication.

Milne, A. (2006). What Is in It for Us? Network Effects and Bank Payment Innovation. Journal of Banking \& Finance, 30, 1613-1630. https://doi.org/10.1016/j.jbankfin.2005.09.006

Morufu, O., \& Taibat, A. (2012). Banker's Perception of Electronic Banking in Nigeria: A Review of Post Consolidation Experience. Research Journal of Finance and Accounting, 3, 5-6.

Nair, A., \& Fissha, A. (2010). Rural Banking: The Case of Rural and Community Banks in Ghana. Agriculture and Rural Development Discussion Paper 48. https://doi.org/10.1596/27725

Nayak, S. K., Throat, S. B., \& Kalyankar, N. V. (2010). Reaching the Unreached: A Role of ICT in Sustainable Rural Development. International Journal of Rural Banks and Information Security, 7, 220-224.

Ovia, J. (2005). Enhancing the Efficiency of the Nigerian Payments System. Central Bank of Nigeria Bullion, 29, 8-18.

Shu, W., \& Strassmann, P. A. (2005). Does Information Technology Provide Banks with Profit? Information and Management, 42, 781-787. 
https://doi.org/10.1016/j.im.2003.06.007

Steel, F. W., \& Andah, O. D. (2003). Review of Rural and Micro Finance Regulation in Ghana: Implications for Development and Performance of the Industry. Africa Region Working Paper Series No. 49, Washington DC: World Bank..

Tsamenyi, M., \& Shazzad, U. (2008). The Case of Rural Banks in Ghana. In Corporate Governance in Less Developed and Emerging Economics (pp. 311-334). Bingley: Emerald Group Publishing.

Tukel, O. I., \& Rom, W. O. (2001). An Empirical Investigation of Project Evaluation Criteria. International Journal of Operations \& Production Management, 21, 400-416. https://doi.org/10.1108/01443570110364704

Xiao, H., \& Proverbs, D. (2003). Factors Influencing Contractor Performance: An International Investigation. Engineering Construction and Architectural Management, 10, 322-332. https://doi.org/10.1108/09699980310502937

Yakhlef, A. (2001). Does the Internet Compete with or Complement Bricks and Mortar Bank Branches? International Journal of Retail \& Distribution Management, 29, 272-281. https://doi.org/10.1108/09590550110393965

\section{Abbreviation}

ICT: Information Communication Technology

SPSS: $\quad$ Statistical Package for Social Sciences

GPRS: Growth and Poverty Reduction Strategy

APR: Annual Progress Report

ARB: Association of Rural Banks

ADB: Agriculture Development Bank

ATM: Automated Teller Machine 